\title{
HELICOBACTER PYLORI INFECTION; A STUDY TO SEE THE PREVALENCE AND ALSO TO VALIDATE VARIOUS ASSOCIATED RISK FACTORS IN POPULATION OF SARGODHA
}

1. MBBS, M. Phil.

Assistant Professor of Pathology Sargodha Medical College, Sargodha.

2. MBBS, M. Phil.

Assistant Professor of Pathology Azra Naheed Medical College, Lahore.

3. B.E.M.S., M. Phil. Scholar, Pathology Sargodha Medical College, Sargodha.

4. B.E.M.S., M. Phil., PhD (Medicine)

Assistant Professor of Eastern Medicine \& Surgery Department of Eastern Medicine \& Surgery, GC University, Faisalabad.

Correspondence Address:

Dr. Tahira Tabassum

52/3 Civil Lines,

Awan Colony, Sargodha

drtahirat@yahoo.com

Article received on:

26/05/2017

Accepted for publication:

10/07/2017

Received after proof reading:

$08 / 09 / 2017$

\section{INTRODUCTION}

Helicobacter pylori (H. pylori) is a microaerophilic, Gram-negative bacterium helical in shape, having length of $3 \mu \mathrm{m}$ and about $0.5 \mu \mathrm{m}$ in diameter and was discovered by Marshall and Warren in $1982 .{ }^{1}$ $\mathrm{H}$. pylori is one of the most common humanspecific pathogens ${ }^{2}$ which can reside in various parts of stomach especially the antrum. ${ }^{3}$

$\mathrm{H}$. pylori causes damages resulting in gastritis and peptic ulceration that can lead to chronic gastric inflammation, gastric cancers such as adenocarcinoma and lymphoma. ${ }^{4}$ Half of the world's population is at risk by this bacterium. It is well-recognized bacterial infection in the world, as in developing nation approximately $75 \%$ and about $40 \%$ of population in the developed countries is being colonized even at early age with this organism. ${ }^{5}$

\begin{abstract}
Tahira Tabassum ${ }^{1}$, Ayesha Imtiaz ${ }^{2}$, Aamir Sharif $^{3}$, Muhammad Akram $^{4}$
\end{abstract} Sargodha from 01.01.2017 to 31.03.2017. Material and Methods: The study was conducted among 486 clinically suspected individuals of Sargodha, Punjab, Pakistan. Data was obtained questionnaire and $\mathrm{H}$. pylori antibodies were detected by $\mathrm{H}$. pylori 'One Step Test Device' in $66.97 \%$ in males and $33.2 \%$ in females $(p=0.00)$ and increased with increasing age $(p=$ 0.000 ). In the study, significant association was found between age groups, education levels, Cof present study showed the prevalence of $\mathrm{H}$. pylori in reported area and confirmed that it is higher in developing countries. It is concluded that prevalence of in this bacterium can be minimized by increasing the hygenicity, improving the living Key words: $\quad$ H. Pylori, Prevalence, Infection, Risk Factors, Population, Sargodha.

Article Citation: Tabassum T, Imtiaz A, Sharif A, Akram M. Helicobacter pylori infection; a study to see the prevalence and also to validate various associated risk factors in population of Sargodha. Professional Med J 2017;24(9):1425-1430. DOI: $10.17957 / \mathrm{TPMJ} / 17.4080$

Household hygiene, sanitation systems and drinking water, have major effects on $\mathrm{H}$. pylori prevalence. According to earlier studies, prevalence of $\mathrm{H}$. pylori was high (92\%) in people who use water from well as compared to tap water drinkers (75\%). Higher prevalence was noted (86 versus $70 \%$ ) among persons with low as compared to higher socioeconomic status. ${ }^{6}$ After successful eradication, recurrence of infection is common in developing countries which also affect the prevalence rate. ${ }^{7}$ Recurrences in developing countries are due to reinfection while in developed nations recrudescence's are considered to be the cause. $^{8}$

The important virulence factors of $\mathrm{H}$. pylori are its spiral shape, motility and urease production which help the bacterium to colonize at mucosal surface of the stomach. ${ }^{9}$ Moreover, several pathogenic proteins such as cytotoxin-associated 
antigen (Cag A) and vacuolating cytotoxin (Vac A) are released by the bacterium. ${ }^{10}$ The cag $A$ gene (type I strains) is responsible for cytotoxinproducing strains of Helicobacter and is mostly isolated from patients having gastric disease. Hence to identify infection with harmful strains detection of cag $A$ is important. ${ }^{11}$

H. pyloritransmission from one person to another is still undefined. Howeverseveral researchersstated various potential factors causingitstransmission. A study on Greek population revealed that $\mathrm{H}$. pylori was more prevalent in siblings and parents of those individuals, who are positive for $\mathrm{H}$. pylori as compared to negative ones. ${ }^{12}$

There is variation in sign and symptoms of $\mathrm{H}$. pylori infection that depend upon the interaction of both host and bacterial factors and the strains of $\mathrm{H}$. pylori. The symptoms include acute gastritis with dyspepsia, heartburn, belching, epigastric pain, nausea and vomiting. However, infected persons are mostly asymptomatic due to shortage of cofactors of host or bacteria or the colonized strains are less virulent. Dyspepsia is a prevalent complaint in general practice and gastrointestinal clinic. ${ }^{9}$

For determination of $\mathrm{H}$. pylori infection invasive and non-invasive techniques are used. They are highly sensitive and specific. Invasive tests include endoscopic biopsy, culturing from tissue, rapid urease test (RUT) and polymerase chain reaction (PCR) ${ }^{13}$ In noninvasive tests $\mathrm{H}$. pylori antibody test, urea breath test, and $\mathrm{H}$. pylori stool antigen test are included. Invasive test is not considered to be better than non-invasive for determination of $\mathrm{H}$. pylori infection and vice versa. ${ }^{14}$ Now a days different ELISA kits having difference in target antigens and antibody preparations are used for the detection of $\mathrm{H}$. pylori. According to geographic regions and populations, the prevalence of antibody against $\mathrm{H}$. pylori varies..$^{15}$ For epidemiological studies serological tests are helpful for determining the prevalence of $\mathrm{H}$. pylori. Simplicity, speed, low cost, and minimal patient discomfort are the advantages of these tests. ${ }^{16}$

In perspective of this, the present study was designed to estimate the prevalence of $\mathrm{H}$. pylori infection in Sargodha (Punjab, Pakistan). This specific study area was chosen because it includes population of both high and low-socioeconomic status and moreover Gl symptoms are very common among people of this area. Furthermore, no research work related to H.pylori has been conducted in this region so far.

\section{MATERIALS AND METHODS}

\section{Study Design}

Descriptive study

\section{Setting}

This study was carried out at UMC\&RC Sargodha Punjab, Pakistan.

\section{Sample Size}

486 subjects were included in this study.

\section{Inclusion criteria}

- Patients having symptoms of dyspepsia, epigastric pain, belching, heartburn, nausea or vomiting.

\section{Exclusion Criteria}

- Patients who had taken any antibiotic, colloidal bismuth compound, proton pump inhibitor in last one month

- Chronic users of corticosteroids or immunosuppressive drugs

- Patients who had ever received H. pylori eradication therapy

- Patients with bleeding peptic ulcer

- Patients who had partial or complete gastrectomy or gastro-jejunostomy.

\section{Acquisition of Specimens}

After informed consent and using aseptic venipuncture technique about $3 \mathrm{ml}$ of blood was collected in sterile gel test tubes from symptomatic individuals. After centrifugation serum was separated from blood samples. Then according to manufacturer instructions $\mathrm{H}$. pylori 'One Step Test Device' with an immune-chromatographic assay was used to detect $\mathrm{H}$. pylori antibodies in suspected serum. After 10 minutes result was noted and appearance of two distinct red lines one 
at control region $(C)$ and other at test region $(T)$ were observed. The presence of both control and test lines represent $\mathrm{H}$. pylori positive and only one red line in control region declare negative result. At that time the subjects were interviewed by one of the authors using a pre-tested questionnaire. Questionnaires contained information on name, age, gender, socioeconomic status, education level, source of drinking water and eating habits weather home cooked or outside.

\section{Statistical Analysis}

Statistical analysis was performed using the SPSS 15.0 statistical software program (SPSS Inc, Chicago, USA). Differences in infection prevalence among different groups were analyzed using $X 2$ test. Variables with $p$ value less than 0.05 were considered significantly associated with $\mathrm{H}$. pylori infection.

\section{RESULTS}

Sample from486 clinically suspected subjects were tested, of which $300(61.72 \%)$ were males and $186(38.27 \%)$ were females with a mean age of $42.5 \pm 13.9$ years (range 16-60 years) (Figure-1). Of these 486 people, 327 were $\mathrm{H}$. pylori positive and 159 were negative (Figure-1). Out of 300 tested males, 219 were reported as positive and 81 were negative for $\mathrm{H}$. pylori antibodies. Similarly 186 females were tested, of which 108 were positive and 78 were negative. The prevalence of $H$. pylori infection in the participants was $67.28 \%$ (327/486) with $66.97 \%$ males and $33.02 \%$ females infected with $H$. pylori infection $(p=0.000)$.

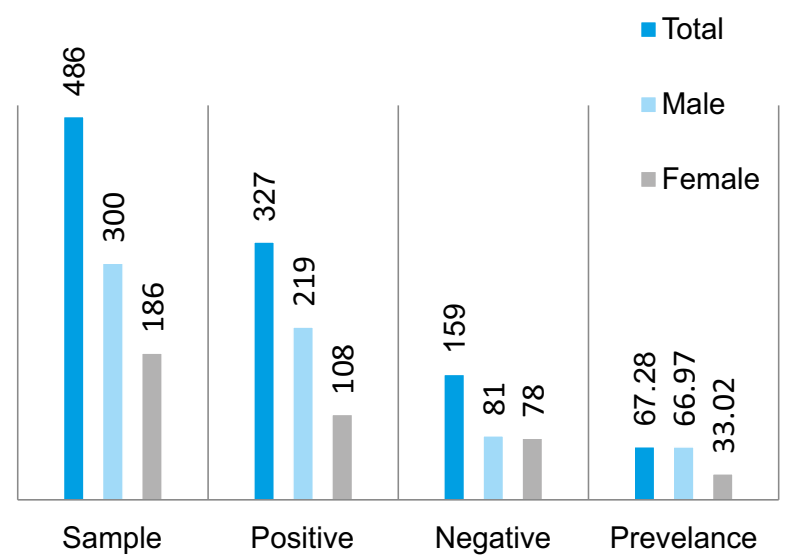

Figure-1. H. pylori infection on the basis of gender
H. pylori antibodies were positive in $93 / 327$ patients (28.44\%) up to 30 years of age, $65 / 327$ $(19.87 \%)$ in patients with age between 30 to 40 years, and 169/327 (51.68\%) in patients above 40 years.

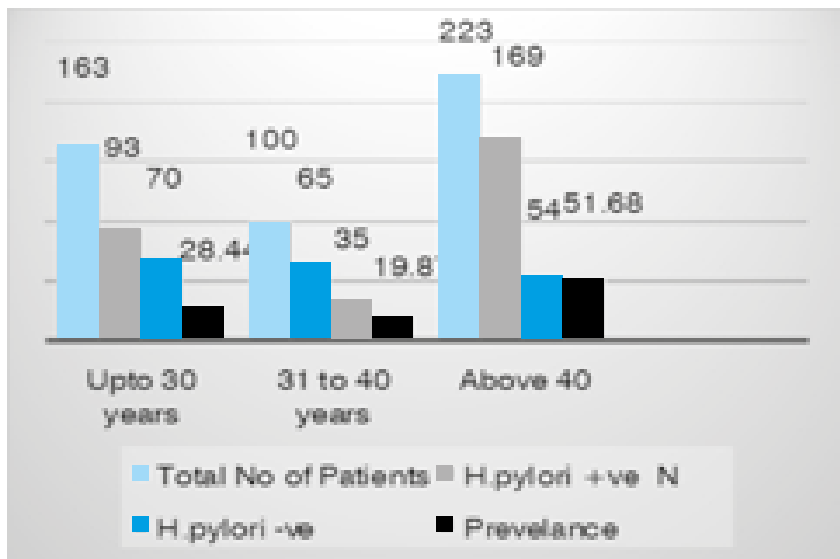

Figure-2. H. pylori infection on the basis of age category

It was observed that prevalence of infection increases with increase in age. In patients up to 30 years of age, prevalence was $57.05 \%, 65 \%$ in $31-40$ years and $75.78 \%$ in patients $>40$ years of age $(p=0.000)$ (Figure-2).

\begin{tabular}{|c|c|c|c|}
\hline Variables & Subjects & Sero + (\%) & $p$ value \\
\hline \multicolumn{4}{|l|}{ Gender } \\
\hline Male & 300 & 219 & \multirow{2}{*}{0.000} \\
\hline Female & 186 & 108 & \\
\hline \multicolumn{4}{|l|}{ Age Group } \\
\hline Up to 30 years & 163 & 93 (57.05\%) & \multirow{3}{*}{0.000} \\
\hline $31-40$ years & 100 & $65(65.00 \%)$ & \\
\hline$>40$ years & 223 & $169(75.78 \%)$ & \\
\hline \multicolumn{4}{|c|}{ Education Levels } \\
\hline Illiterate & 85 & $68(80.00 \%)$ & \multirow{5}{*}{0.000} \\
\hline $\begin{array}{l}\text { Primary } \\
\text { School }\end{array}$ & 121 & 94 (77.68\%) & \\
\hline Middle School & 97 & $63(64.94 \%)$ & \\
\hline High School & 104 & $62(59.61 \%)$ & \\
\hline $\begin{array}{l}\text { College and } \\
\text { University }\end{array}$ & 79 & $40(50.63 \%)$ & \\
\hline \multicolumn{4}{|c|}{ Source of Drinking Water } \\
\hline City water & 190 & $125(65.78 \%)$ & \multirow{2}{*}{0.321} \\
\hline Boring water & 296 & 202 (68.24\%) & \\
\hline \multicolumn{4}{|l|}{ Food Habits } \\
\hline Home cooked & 163 & 93 (57.05\%) & \multirow[b]{2}{*}{0.001} \\
\hline $\begin{array}{l}\text { Hotel / Hostel } \\
\text { cooked }\end{array}$ & 323 & 234 (72.44\%) & \\
\hline \multicolumn{4}{|c|}{$\begin{array}{l}\text { cooked } \\
\text { Monthly Income }\end{array}$} \\
\hline $5001-20000$ & 143 & $105(73.42 \%)$ & \multirow{3}{*}{0.041} \\
\hline $20001-35000$ & 267 & $176(65.91 \%)$ & \\
\hline $35001-50000$ & 76 & $46(60.52 \%)$ & \\
\hline \multicolumn{4}{|c|}{$\begin{array}{c}\text { Table-I. Association of } \mathrm{H} \text {. pylori infection with study } \\
\text { variables }\end{array}$} \\
\hline
\end{tabular}


In the study, significant association was found between $\mathrm{H}$. pylori infection and education levels of patients that were categorized in groups of Illiterate $(80.00 \%, 68 / 85)$, primary school $(77.68 \%$, $94 / 121)$, middle school (64.94\%, 63/97), high school $(59.61,62 / 104)$ and college and university $(50.63 \%, 40 / 79)$ with $p$ value 0.000 as shown in Table-I.

Among city water users $\mathrm{H}$. pylori prevalence was found to be $65.78 \%(125 / 190)$ as compared to consumers of boring water having prevalence of $68.24 \%(202 / 296)$. No significant association was seen for source of drinking water $(p=0.321)$ as shown in Table-I.

The prevalence of $\mathrm{H}$. pylori infection in the group who ate home cooked food (57.05\%, 93/163) was lower as compared to the group using hotel or hostel cooked food $(72.44 \% 234 / 323)$, with significant statistical difference $(p=0.001)$ as shown in Table-I.

As for the association of prevalence and economic status, in the three groups (Lower, Middle and upper class), it was found that individuals having monthly income of 5001-20000 had $73.42 \%$ (105/143) while those having20001-35000 and 35001-50000 monthly income had $65.91 \%$ $(176 / 267)$ and $60.52 \%(46 / 76)$ of $H$. pylori infection, respectively, and the difference was statistically significant ( $p=0.41$ ) Table-I.

\section{DISCUSSION}

Prevalence of $\mathrm{H}$. pylori remarkably varies among developed and underdeveloped countries. ${ }^{17}$ In Sargodha region there is a lack of data about the prevalence of infection. In this study we determined the prevalence and associated risk factors of $\mathrm{H}$. pylori. The overall prevalence rate was $67.28 \%$. In another study conducted by Rasheed et al. $(2012)^{18}$ the prevalence rate was $74 \%$.

There was a significant difference in prevalence among women and men. The results of a similar study conducted by Dube et al. (2009) ${ }^{19}$ are in agreement with this finding but there is a conflict with another study performed by Sasidharan and Uyub $(2009)^{20}$ which state that the infection rate is higher in females than in males. Malepredominance of the infection is justified probably due to the fact that males are more in a habit of consuming outside food from hotels or restaurants.

We found a direct correlation between infection rate and age. Seroprevalence was found to be higher in older age groups. This finding is in accordance with the results of Mbulaiteye et al. (2006). ${ }^{21}$

Seroprevalence decreased with increasing education level of the participants. The results are compatible with the study carried out by Sykora et al. (2009) ${ }^{22}$ and contradicts with Rasheed et al. (2012) ${ }^{18}$ and can be justified by better economic and hygienic status in more educated persons. The implication of this finding is that the prevalence of the infection will decrease in the future, since the education level is increasing in the region.

In studied area, drinking water is obtained from different sources including city water / municipal supply, and boring water. The boring water is located usually inside the house and occasionally near to open toilet and improper purification system make water more prone to contamination. Hulten et al. (1996) reported that $H$. pylori was isolated from water. ${ }^{23}$ But in current study no significant relationship was found between source of drinking-water and $\mathrm{H}$. pylori infection, though prevalence of $\mathrm{H}$. pylori infection was high among city and boring water consumers. This is consistent with the study conducted by Rasheed et al. (2009). ${ }^{18}$

In this study, it was found that people residing in hostels or eating at hotels or restaurants have higher $\mathrm{H}$. pylori infection as compared to people taking home made food. This study is not compatible with Jahan et al. (2010). ${ }^{24}$ They found that students residing in hostels or eating from the restaurants had no significant effect on seropositivity of $\mathrm{H}$. pylori.

As for the monthly household income, we observed that when the income was higher 
prevalence was low which is consistent with Zhu et al. (2014). ${ }^{25}$ This might be due to the better sanitary and living conditions.

\section{CONCLUSIONS}

Following conclusions are drawn from present study:

1. H. pylori infection is still prevalent in underdeveloped countries. There is direct correlation between infection rate and age, being higher in older age groups.

2. There is slight variation in $\mathrm{H}$. pylori infection on the basis of gender, being somewhat higher in males as compared to the females.

3. Seroprevalence decreased with increasing education level and can be justified by better economic and hygienic status in more educated persons.

4. Household hygiene and sanitation systems have major effects on $\mathrm{H}$. pylori prevalence. People residing in hostels or eating at hotels or restaurants have higher $\mathrm{H}$. pylori infection as compared to people taking home made food.

5. Prevalence is found to be low in people with higher socio-economic status or vice versa. This might be due to the better sanitary and living conditions.

6. It is therefore concluded that prevalence of infection with this bacterium can be minimized by increasing the hygenicity, improving the living standards and, of course, by educating the nation.

\section{Copyright@ 10 July, 2017.}

\section{REFERENCES}

1. Ahmed, N., 23 years of the discovery of Helicobacter pylori: Is the debate over? Annals of clinical microbiology and antimicrobials, 2005. 4(1): p. 17.

2. Logan, R.P. and M.M. Walker, Epidemiology and diagnosis of Helicobacter pylori infection. British medical journal, 2001. 323(7318): p. 920.

3. Marshall, B. and J.R. Warren, Unidentified curved bacilli in the stomach of patients with gastritis and peptic ulceration. The Lancet, 1984. 323(8390): p. 1311-1315.

4. Thung, l., et al., Review article: the global emergence of Helicobacter pylori antibiotic resistance. Alimentary pharmacology \& therapeutics, 2016. 43(4): p. 514-533.

5. Akçam, M., Helicobacter pylori and micronutrients. Indian pediatrics, 2010. 47(2): p. 119-126.

6. Ahmed, K., et al., Impact of household hygiene and water source on the prevalence and transmission of Helicobacter pylori: a South Indian perspective. Singapore medical journal, 2007. 48(6): p. 543.

7. Gisbert, J.P., The recurrence of Helicobacter pylori infection: incidence and variables influencing it. $A$ critical review. The American journal of gastroenterology, 2005. 100(9): p. 2083-2099.

8. Niv, Y. and R. Hazazi, Helicobacter pylori recurrence in developed and developing countries: meta $\square$ analysis of $13 \mathrm{C} \square$ urea breath test follow $\square$ up after eradication. Helicobacter, 2008. 13(1): p. 56-61.

9. Dubois, A., Spiral bacteria in the human stomach: the gastric helicobacters. Emerging infectious diseases, 1995. 1(3): p. 79

10. Jones, K.R., J.M. Whitmire, and D.S. Merrell, A tale of two toxins: Helicobacter pylori CagA and VacA modulate host pathways that impact disease. Frontiers in microbiology, 2010. 1: p. 115.

11. Andreson, $H_{\text {., }}$ et al., Association of cagA and vacA genotypes of Helicobacter pylori with gastric diseases in Estonia. Journal of clinical microbiology, 2002. 40(1): p. 298-300.

12. Roma, E., et al., Intrafamilial spread of Helicobacter pylori infection in Greece. Journal of clinical gastroenterology, 2009. 43(8): p. 711-715.

13. Garza-González, E., et al., A review of Helicobacter pylori diagnosis, treatment, and methods to detect eradication. World J Gastroenterol, 2014. 20(6): p. 1438-1449.

14. Testerman, T.L. and J. Morris, Beyond the stomach: an updated view of Helicobacter pylori pathogenesis, diagnosis, and treatment. World J Gastroenterol, 2014. 20(36): p. 12781-12808.

15. Laheij, R., et al., Evaluation of Commercially AvailableHelicobacter pylori Serology Kits: a Review. Journal of clinical microbiology, 1998. 36(10): p. 28032809.

16. Leal, Y.A., et al., Antibody-based detection tests for the diagnosis of Helicobacter pylori infection in children: a meta-analysis. PLoS One, 2008. 3(11): p. e3751.

17. Perez Perez, G.I., D. Rothenbacher, and H. Brenner, Epidemiology of Helicobacter pylori infection. 
Helicobacter, 2004. 9(s1): p. 1-6.

18. Rasheed, F., T. Ahmad, and R. Bilal, Prevalence and risk factors of Helicobacter pylori infection among Pakistani population. 2012.

19. Sasidharan, S. and A. Uyub, Prevalence of Helicobacter pylori infection among asymptomatic healthy blood donors in Northern Peninsular Malaysia. Transactions of the Royal Society of Tropical Medicine and Hygiene, 2009. 103(4): p. 395-398.

20. Tam, Y.H., et al., A Population Based Study of Helicobacter pylori Infection in Chinese Children Resident in Hong Kong: Prevalence and Potential Risk Factors. Helicobacter, 2008. 13(3): p. 219-224.

21. Mbulaiteye, S.M., et al., H. Pylori-infection and antibody immune response in a rural Tanzanian population. Infectious agents and cancer, 2006. 1(1): p. 3.

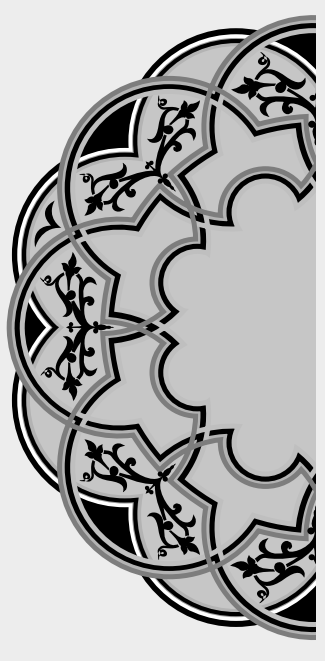

22. Sýkora, J., et al., Epidemiology of Helicobacter pylori Infection in Asymptomatic Children: A Prospective Population $\square$ Based Study from the Czech Republic. Application of a Monoclonal $\square$ Based Antigen in Stool Enzyme Immunoassay. Helicobacter, 2009. 14(4): p. 286-297.

23. Hulten, K., et al., Helicobacter pylori in the drinking water in Peru. Gastroenterology, 1996. 110(4): p. 10311035.

24. Jahan, H., O. Chowdhury, and M. Uddin, Helicobacter pylori infection on medical students: A study on MAG Osmani Medical College, Bangladesh. International Journal of Medicine and Medical Sciences, 2010. 2(11): p. 354-358.

25. Zhu, Y., et al., Risk factors and prevalence of Helicobacter pylori infection in persistent high incidence area of gastric carcinoma in Yangzhong city. Gastroenterology research and practice, 2014. 2014.

\title{
"Use soft words and hard arguments."
}

\author{
Unknown
}

\section{AUTHORSHIP AND CONTRIBUTION DECLARATION}

\begin{tabular}{|c|c|c|c|}
\hline Sr. \# & Author-s Full Name & Contribution to the paper & Author $=$ s Signature \\
\hline 1 & Tahira Tabassum & $\begin{array}{l}\text { Contribusion to conception and } \\
\text { design, acquisition of data, analysis }\end{array}$ & \\
\hline 2 & Ayesha Imtiaz & $\begin{array}{l}\text { Drafting of article, analysis of data } \\
\text { and shares its expert research } \\
\text { opinion in finalizing the manuscript }\end{array}$ & \\
\hline 3 & Aamir Sharif & $\begin{array}{l}\text { Analysis and interpretation of data. } \\
\text { Contributed in conception and }\end{array}$ & \\
\hline 4 & Muhammad Akram & $\begin{array}{l}\text { shares its expert research opinion. } \\
\text { Interpretation of daat. Contribution in } \\
\text { conception and design. }\end{array}$ & \\
\hline
\end{tabular}

